\title{
Study of Estrogen, Progesterone, Copper, Zinc and some Antioxidants in Sera of Ovarian Cancer Patients
}

\author{
Rana T. Ibrahim \\ Department of Chemistry \\ College of Education \\ University of Mosul
}

(Received 17 / 10 / 2012 ; Accepted 28 / 1 / 2013)

\begin{abstract}
The research was concerned with a study of the relationship between patients with ovarian cancer (OCa) and some biochemical parameters.

Serum samples were collected from (25) healthy females and (25) females with ovarian cancer. The measured parameters in sera included the level of estrogen, progesterone hormones, some trace elements (copper and zinc), as well as some antioxidants such as glutathione, ceruloplasmin and malondialdehyde (MDA).

Total protein was also measured in the present study. Compared with the healthy females, the females ovarian cancer exhibited a significant increase in the level of estrogen and progesterone hormones, ceruloplasmin, MDA and copper. They also exhibited a significant decrease in the level of glutathione, total protein and zinc.
\end{abstract}

Keywords: Ovarian cancer, oestrogen and progesterone hormones, zinc, copper, antioxidant.

\section{درلسة الستروجين، البروجستيرض، النحل، الخارصسن وصضمضاكل الكسةفي مطل ثم:مربضاتسسولن المبيض}

\section{المالغص}

تضمن البهث درلسة علاقةسرطان المبيض مع بعض المتغيرات الكيموحيوية. حيث جمعت نماذج من مصل الدم من (25) إمرأة من النساء للسليملت و(25) إمرأة من النساء المصابلت بسرطان المنان المبيض.

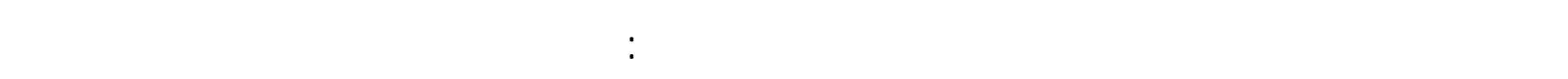

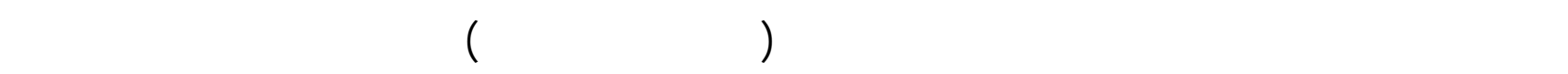

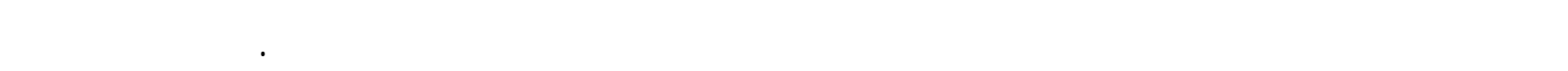

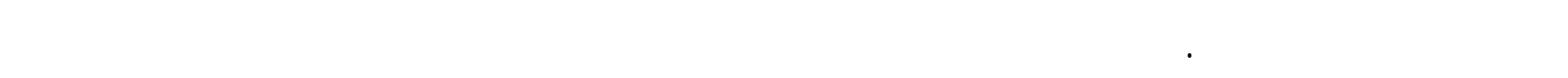

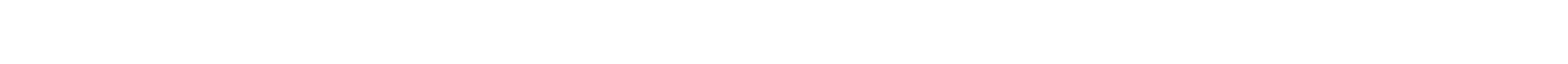
الكلوتاثايون والبروتين الكلي والخارصنين في النساء المصابلت مقارينة مع النساء للسليمات. 


\section{INTRODUCTION}

Cancer is a disease in which cells in the body grow out of control. As the cells grow and multiply, they form masses called tumors (Doll and Peto, 1988). The ovaries are the main source of the females' hormones estrogen and progesterone. Estrogens (estradiol, estrone, estriol) are predominately female hormones, and in adults they are important for maintaining the health of the reproductive tissues, breast, skin and brian (Maker, 2000).

Progesterone is a hormonal balancer, particularly of estrogen. It enhances the beneficial effect of estrogens while mitigating the problems associated with estrogen excess, natural progesterone helps regulate apoptosis and also helps create a balance of all other steroid hormones (Shuk- Mei, 2003).

Ovarian cancer is a cancer that begins in one or both of woman's ovaries, it is the leading cause of death from all gynecology malignancies (Maker, 2000).

Most (more than 90\%) ovarian cancers are classified as "epithelial". These tumors arise from a layer of cells that surrounds the outside of the ovary called the germinal epithelium mostly common in women over 45 years (Cannistra, 2004).

The major role in ovarian cancer initiation and progression is DNA damage, mostly caused by oxidative stress, which is an imbalance between the formation of reactive oxygen species (ROS) and antioxidative defense mechanisms (Sanjyotoi and Melinkeri, 2011 ; Gina et al., 2009). Inadequate antioxidant production or excess production of free radicals, particularly oxygen radicals creates oxidative stress, which causes cell damage and plays a fundamental role in various diseases like cancer (Naidu et al., 2007; Pijic et al., 2006).

The majority of ovarian cancers are thought to be originated from a surface epithelial cell perturbed by ovulation (William and James, 2004). The reactive oxidants (hydroxyl radical, superoxide radicals, hydrogen peroxide and singlet oxygen) which are generated during the mechanics of ovulatory follicular rupture damage the DNA of ovarian surface epithelial cells that are located within limited diffusion radius (Sanjyotoi and Melinkeri, 2011). Recent molecular studies have shown that ovarian cancer has aquired genetic alteration of concogenes and tumor suppressor genes such as BRCA 1, P53, nm23 and K-ras, which may be due to inflammation and oxidative stress (Barrt, 2007; Sanjyotoi and Melinkeri, 2011).

The present research deals with studying the effect of ovarian cancer on the levels of some hormones, trace elements, antioxidant and total protien in ovarian cancer patients compared to control females.

\section{Subjects}

\section{MATERIALS AND METHODS}

The subjects included two groups, patient and healthy, aged (49-69). The patient group consisted of (25) females with ovarian cancer who were diagnosed by specialist doctors. The collected samples were obtained at tumor and nuclear medicine hospital (Al-Hafith Hospital) in Mosul City. The healthy (control) group consisted of (25) healthy females.

Both groups (patient and healthy) were in postmenopausal period, and free from any other gynecologic malignancies like breast, cervical, uterine cancers and also any concomitant illnesses such as diabetes mellitus and cardiovascular diseases.

\section{Sample Collection and Analysis:}

Venous blood samples were drawn from each patient then transferred immediately to a 
clean dry plastic tubes. The blood was allowed to clot for at least (10-15) min. at room temperature and then centrifuged for (10) min. at (3500 rpm). Serum was collected and used to measure some biochemical parameters (Burits and Ashwood, 1999).

\section{Methods:}

Estrogen and progesterone hormones were determined by mini VIDAS analyzer (Bio Merieux Vitek, USA) using Enzyme Linked Fluorescent Assay (But and Blunt, 1988 ; Diver, 1987).

Ceruloplasmine level was determined by oxidization method based on the ability of ceruloplasmine to catalyse the oxidation of colorless para-phenylene diamine to a blueviolet complex, which can be spectrophotometrically estimated (Sunderman and Nomato, 1970).

Glutathione level was determined by using the modified method described by (Sedlak and Lindsay, 1968) based on using Ellman's reagent (DTNB).

Serum lipid peroxidation was determined by thiobarbituric acid modified procerdure (Guidet and Shah, 1989).

The level of serum trace elements ( $\mathrm{Cu}$ and $\mathrm{Zn}$ ) was determined using atomic absorption spectrophotometer (Willard et al.,1974) in Biology Department, College of Science.

Serum total protein was determined by Biuret method (Plummer, 1978) using kit manufactured by RANDOX (United Kingdom).

\section{STATISTICAL ANALYSIS}

The data were subjected to statistical analysis using Student's unpaired t-test for comparison of means between patients and controls.

All the data were expressed as mean \pm standard deviation of the mean $\mathrm{p}-$ values. The values of 0.05 or less were considered significant.

\section{RESULTS AND DISCUSSION}

The results of the measured biochemical parameters are summarized in table (1).

\section{Estrogen and Progesterone Hormones:}

The results in Table (1) showed a significant increase $(p \leq 0.05)$ in the level of estrogen and progesterone hormones in ovarian cancer patients compared to the healthy control group. The obtained results were in agreement with other investigations which suggest that steroid hormones, primarily estrogen and progesterone, are implicated in ovarian carcinogenesis (Shuk-Mei, 2003).

The epidemiological evidence is strongly suggests that steroid hormones, estrogen and progesterone, are implicated in ovarian cancer. Estrogens favor neoplastic transformation of the ovarian surface epithelium (OSE), while progesterone offers protection against ovarian cancer development. Specifically, estrogens, particularly those present in ovulatory follicles, are both genotoxic and mitogenetic to OSE cells. In contrast, pregnancy-equivalent levels progesterone are highly effective as apoptosis inducers for ovarian surface epithelium and ovarian cancer cells. In this regard, high-dose progestin may exert an exfoliation effect and rid an aged OSE of pre-malignant cells (Maker, 2000; Issa et al., 2009). Many studies suggested that ovarian cancer cells under estrogen control containing estrogen-receptors, which are bound with estrogen hormone to form a complex which is bound to promoter 
regions of specific genes to activate the transcription of new mRNA and continue this process (Shuk-Mei, 2003; Issa et al., 2009; David, 2003).

Moreover, ovarian cancer has been linked to an increased amount of estrogen activity in the body. Excess fat can cause the body to retain estrogen and may convert other hormones into a form of estrogen, increasing the risk of ovarian cancer (Wolin et al., 2010).

It was reported (Lee et al., 2009) that $86 \%$ of ovarian tumor specimens stained positive for estrogen receptors and $50 \%$ positive for progesterone receptors.

Finally, some recent studies suggest that the use of menopausal hormone replacement therapy (HRT) is associated with the increase of rise ovarian cancer particularly in longtime using and users of sequential estrogen-progesterone schedules (James et al., 2002; Anderson, 2003).

Table 1: The means of biochemical parameters in patient and control groups

\begin{tabular}{|l|c|c|c|}
\hline \multirow{2}{*}{ Parameters } & \multicolumn{2}{c|}{ Mean \pm SD } & \multirow{2}{*}{$p$-value } \\
\cline { 2 - 3 } & $\begin{array}{c}\text { Healthy Women } \\
(\mathbf{n}=\mathbf{2 5})\end{array}$ & $\begin{array}{c}\text { Ovarian Cancer } \\
\text { Women }(\mathbf{n}=\mathbf{2 5})\end{array}$ & \\
\hline 1. Estrogen Hormone $(\mathrm{pg} / \mathrm{mL})$ & $6.60 \pm 1.30$ & $22.14 \pm 2.34$ & $p \leq 0.05$ \\
\hline 2. Progesterone Hormone $(\mathrm{pg} / \mathrm{mL})$ & $2.26 \pm 0.71$ & $7.08 \pm 1.96$ & $p \leq 0.05$ \\
\hline 3. Ceruloplasmin $(\mu \mathrm{mol} / \mathrm{L})$ & $190.21 \pm 24.83$ & $231.62 \pm 33.17$ & $p \leq 0.05$ \\
\hline 4. Glutathione $(\mu \mathrm{mol} / \mathrm{L})$ & $11.73 \pm 1.53$ & $7.27 \pm 1.33$ & $p \leq 0.05$ \\
\hline 5. MDA $(\mu \mathrm{mol} / \mathrm{L})$ & $0.20 \pm 0.076$ & $0.49 \pm 0.15$ & $p \leq 0.05$ \\
\hline 6. Copper $(\mu \mathrm{mol} / \mathrm{L})$ & $8.50 \pm 2.86$ & $14.13 \pm 3.26$ & $p \leq 0.05$ \\
\hline 7. Zinc $(\mu \mathrm{mol} / \mathrm{L})$ & $16.05 \pm 1.52$ & $10.38 \pm 3.76$ & $p \leq 0.05$ \\
\hline 8. Total Protein $(\mathrm{gm} / \mathrm{L})$ & $61.42 \pm 14.35$ & $49.94 \pm 10.54$ & $p \leq 0.05$ \\
\hline
\end{tabular}

\section{Ceruloplasmin (CP):}

Statistical analysis (Table 1) showed a significant increase $(p \leq 0.05)$ in the ceruloplasmin level in serum of ovarian cancer patients compared to control group. This finding agrees with those reported by other investigators (Shivananda et al., 2004 ; Knekt et al.,1992), which showed a high ceruloplasmin level in ovarian cancer patients.

Several studies showed that ceruloplasmin concentration increased in breast, liver, cervix, endometrium and gastrointestinal cancer (Shivananda et al., 2005; Alper et al., 2005; Chan et al.,1993).

Ceruloplasmin increase may due to the fact that it is one of the many acute phase reactant proteins synthesized in the liver in response to various stimuli. Many of these internal and external stimuli resulting in liver disorders may be related to acute or chronic infection, and several other conditions, including cancer, may similarly lead to an increased synthesis of ceruloplasmin (Knekt et al.,1992). 


\section{Glutathione (GSH):}

The result in Table (1) showed a significant decrease in glutathione level in serum of ovarian cancer $(p \leq 0.05)$ when compared with the control group. This finding agrees with those reported by other investigation (Iyoti et al., 2009), which showed a lower glutathione levels in ovarian cancer patients. Several studies showed that GSH concentration decreased in cervical, uterine and colorectal cancer (Iyoti et al., 2009; Skrzydlewska et al., 2005).

Reduction of glutathione level might be due to the increased turnover, for preventing oxidative damage to these patients suggesting an increased defense against oxidant damage in ovarian cancer (Tasf et al., 2005). Glutathione can play as an antioxidant in many different ways directly as a free radical scavenger or as a co-substrate of some enzyme like glutathione peroxidase. The lower levels of glutathione may favor an overproduction of free radicals and lipid peroxides which in turn may induce damage to the cell membrane and DNA (Iyoti et al., 2009 ; Suleyman et al., 2003).

\section{Malondialdehyde (MDA):}

Table (1) showed a significant increase in MDA concentration in serum of ovarian cancer patients $(p \leq 0.05)$ when compared with the control group. The results were in agreement with other investigations (Sanjyotoi and Melinker, 2011), which showed an increase in concentration of MDA produced in serum of ovarian cancer.

The reason for the increased MDA concentration possibly due to excessive oxidation initiators which are increased as the disease transfered from one or both ovaries to other organs while levels of antioxidants are decreased (Anbazhagen and Chellappan, 2009).

Also it might be due to morbidity of ovarian cancer, since ovarian cancer patient undergo oxidative stress which leads to break down cell components by free radical and reactive oxygen species (ROS) as a result of increasing its concentration in the body and decreasing the efficiency of antioxidants system (Sanjyotoi and Melinker, 2011; Weinstein et al., 2000). In most cases of diseases which cause oxidative stress including the cancer tumors, the activity of free radicals increases more than the ability of antioxidants to remove the dangerous effect of free radicals. All of these lead to increase lipid peroxidation and increase the level of MDA resulting in a loss in the balance between the activity of free radical and the activity of antioxidants which cause the oxidative stress, and increase the level of MDA resulting in a loss in the mobility of epithelial membrane (AL-Hassany, 2005).

\section{Copper $(\mathrm{Cu})^{++}$:}

The level of copper ion in serum of patients with ovarian cancer are found to be significantly increased ( $p \leq 0.05$ ), when compared to control group as shown in Table (1). Similar results were shown by others (Shivananda et al., 2004; Margalioth et al., 2006).

High levels of copper have been found in many types of human cancer as well as ovarian cancer, such as breast, prostate, colon, lung, liver and brain (Shivananda et al., 2005; Nazmus et al., 2008). Copper is an important microelement which is not only regulate the physiological functions of various organs but is also associated in the production of pathological changes in these organs by interacting with the bases of DNA which leads to an extensive mutation in DNA (Nazmus et al., 2008; Singh et al., 1990).

In addition to it's affectivity in the processes of angiogenesis of the tumor (the growth of tumor blood supply), which lead to the growth, invasion and metastasis of tumor, these lead to increase the level of serum copper in patient with cancer (Skibniewska et al., 2010). 


\section{Zinc $\left(\mathrm{Zn}^{++}\right)$:}

The serum Zn ion level was significantly lower in the ovarian cancer patients ( $p \leq$ 0.05) than in the control group as shown in Table (1). The obtained results were in agreement with those reported by others (Cetinkaya et al.,1994).

It was noted (Altaee, 2003) that the zinc concentration in serum of patients with different types of cancer was significantly decreased when compared with control groups.

Zinc acts as a cellular growth protector, including growth of neoplastic cells, and its deficiency was demonstrated to be involved in several stages of malignant transformation.

Zinc is known to be essential for more than a hundred different metabolic functions, it induce DNA synthesis. It is also essential for the activation of adenyl kinase, phosphodiesterase, membrane-bound adenyl cyclase and lipid peroxidase (Nazmus et al., 2008). Experimentally, zinc deficiency and zinc supplementation have been shown to inhibit or stimulate responses on tumor growth, adding confusion to the role of zinc in human cancer (Arinola and Charles-Davies, 2008).

\section{Total Serum Protein (TSP):}

The level of total serum protein of patients with ovarian cancer was found to be significantly decreased $(p \leq 0.05)$ as shown in Table (1) compared to control group.

Several studies showed that total protein concentration decreased in different types of cancer like breast and respirotry cancer. (AL-Hassany, 2005; Ahmad and Ali, 2007).

The reason for the decreasing of total serum protein might be due to the high level of the oxidative stress whose occurrence due to the ovarian cancer and leads to the consumption of the antioxidant and then to the oxidation of the other biological molecules like protein and form protein hydroperoxides which has a big role to increase the chance for cancer formation due to this reaction with DNA, then causing the genetic mutation in biological molecules (Valko, 2006). It also might be due to the nutritional deficiency and weight loss in association with the psychological distress and lower quality of life (Ovesen et al.,1993).

\section{REFERENCES}

Ahmad, T.Y.; Ali, W.K. (2007). Some biochemical parameters in bearst cancer. Raf. J. Sci., 18(2) 46-57.

AL-Hassany, O.M. (2005). Effect of some tumors in lipid peroxidation and glutathion level and some change in some blood component. M. Sc. Thesis, College of Science, University of Mosul, Iraq.

Alper, B.; Osman, E.; Mehemet, Y.; Nazif, E.; Baysal, K. (2005). The value of serum zinc, copper, ceruloplasmin level in patient with gastriontestinal tract cancer. Turk. J. Cast., 16 (2), 81-84.

Altaee, A.H. (2003). A new relationship between cytidin deamine activity and cancer via oxidative hypothesis. M. Sc. Thesis, College of Science, Univrsity of Babylon, Iraq.

Anbazhagen, M.; Chellappan, P.R. (2009). Activities of antioxidant enzyme and lipid peroxidation in ovarian cancer patients. Aca. J. Cancer Research, 2(2), 68-72.

Anderson, G.L.; Judd, H.L.; Kaunitz, A.M. (2003). Effect of estrogen plus progestin on gyncologic cancer and associated diagnostic procedures: the women's health initiative randomized trial. Jama. J., 290 (13), 1739-1748.

Arinola, O.C.; Charless-Davies, M.A. (2008). Micronutrint in plasma of nigerian females with breast cancer. African J. Biotechnology, 7(11), 1620-1623. 
Barrt, H.W. (2007). Oxidative Stress and Cancer: have we moved forward? Biochem. J., 401,1-11.

Burits, C.A.; Ashwood, E.R. (1999). "Tietz Text Book of Clinical Chemistry". 3rd ed. W.B. Saunders Combany, USA, A Division of Harcourt Brace and Company, Philadelphia. pp.1239-1250.

But, W.R.; Blunt, S.M. (1988). The role of the laboratory in the investigation of infirmity. Ann. Clin. Biochem., 25, 601-609.

Cannistra, S.A. (2004). Cancer of the ovary. J. Med., 351(24), 2519-2529.

Cetinkaya, N.; Deurak, C.; Yüce, M. (1994). Serum copper, zinc levels and copper zinc ratio in healthy women and women with gynecologyical tumors. Biological Trace Element Research, 18 (1), 31-38.

Chan, A.; Wong, F.; Arumanayagam, M. (1993). Serum ultrafiltrable copper, total copper and ceruloplasmin concentration in gynaeacological carcinomas. Ann. Clin. Biochem., 30, 545-549.

David, S.G. (2003). Estrogen Receptor. From Wikipeda, The Free Encyclopedia. http://www.rcsb.org/pdb/static.do?

Diver, M.J. (1987). Plasma progesterone concentration. Clin. Chem., 33(10),1-9.

Doll, R.; Peto, R. (1988). The causes of cancer: quantitative estimates of avoidable risk of cancer in the united state today. J. Natl. Cancer Inst., 66, 1191-1208.

Gina, M.; Marian, T.N.; Teodora, M.N. (2009). Reactive oxygen species, cancer and anticancer therapies. Current Chemical Biology, 3, 342-366.

Guidet, B.; Shah, S.V. (1989). Am. J. Physiol., 257(26), 440 cited by Muslish et al., 2002.

Issa, R.M.; Lebean, A.; Grob, T.; Holest, F. (2009). Estrogen receptor gene amplification occurs rarely in ovarian cancer. Modern Pathology, 22(2), 191-196.

Iyoti, S.; Neelima, S.; Biharilal, S.S.; Achala, S. (2009). Study of blood level of antioxidant enzymes and erythrocyte malondialdehyde (MDA) in ovarian, cervical and uterine cancer at stage I. J. Obstet. Gyecol. 59(3), 242-245.

James, V.L.; Pamela, J.M.; Jay, H.L.; Mark, E.S. (2002). Menopausal hormon replacement therapy and risk of ovarian cancer. Jama. J. 288 (3), 334-341.

Knent, P.; Aromaa, A.; Maatela, J.; Rissanen, A.; Hakama, A.; Aaran, R. (1992). Serum ceruloplasmin and risk of cancer in finland. Br. J. Cancer., 65, 292-296.

Lee, R.M.; Lebean, A.; Grob, T.; Holest, F. (2009). Estrogen receptor gene amplification occurs rarely in ovarian cancer. Modren Pathology, 22(2), 191-196.

Maker, M.P. (2000). Hormone therapy in epithelial ovarian cancer. Endocrine-Related Cancer, 7, 85-93.

Margalioth, E.J.; Udassin, R.; Maor, J.; Schenker, J.G. (2006). Serum copper level in ovarian carcinoma. American Cancer Society, 56, 856-859.

Naidu, M.S.; Suryakar, A.N.; Swami, S.C.; Katkam, R.V.; Kumbar, K.M. (2007). Oxidative stress and antioxidant status in cervical cancer patients. Indian J. Clini. Biochem., 22 (2), 195-45.

Nazmus, A.S.; Hossain, M.I.; Hossian, M.K.; Reza, M.S.; Nahar, Z.; Islam, S.N.; Hasnat, A. (2008). Serum trace elements and immunoglobuin profile in lung cancer patients. J. Appli. Research, 8(1), 24-32.

Ovesen, L.; Hannibal, J.; Mortensen, E.L. (1993). The interrelationship of weigh loss dietary intake and quality of life in ambulatory patients with cancer of the lung, breast and ovary. Nutr. Cancer, 19(2), 156-167. 
Pijic, S.; Kasapovic, J.; Todorovic, A.; Stojilikovic, V.; Pajovic, S.B. (2006). Lipid peroxidation and antioxidant status in blood of patient with uterine myoma, endometrial polyus, hyperplastic and malignant endometrium. Biological Research, 39(4), 619-629.

Plummer, D.T. (1978). "Introduction to Partical Biochemistry". 2nd ed. McGraw-Hill Book Company, UK.

Sanjyotoi, B.; Melinker, R. (2011). Oxidative stress and antioxidanat status in patient of ovarian cancer. Biomedical Research, 22(2), 193-197.

Sedlak, J.; Linsay, R.H. (1968). Anlytical biochemistry. 192 p. cited by AL-Zamyle, O.M.; AL-Nimer, M.S.; AL-Muslih, R.K. (2001). Detection the level of peroxynitrite and related with antioxidant status in the serum of patients with acute myocardial infarction. Nat. J. Chem., 4, 625-637.

Shivananda, B.N.; Vinutha, R.B.; Srimathi, S.M. (2004). Serum copper, ceruloplasmine and thiobarbituric acid reactive substance status in patients with ovarian cancer. Indian. $J$. Physiol., 48(4), 486-488.

Shivananda, B.N.; Yashwanth, S.; Sneha, M.P.; Vinutha, R.B.; Srimathi, S.M. (2005). Serum copper, ceruloplasmine and thiobarbituric acid reactive substance status in liver cancer associated with elevated pharmacol. Indian J. Phsiol., 49(3), 341-344.

Shuk-Mei, H.O.(2003). Estrogen, progesterone and epitheial ovarian cancer. Reproductive Biology and Endocrinology.,1,1-18.

Singh, M.; Dwivedi, S.; Singh, G.; Bajpai, M. (1990). Serum copper levels in different stage of carcinoma. Ind. J. Matern Child. Health Mar., 1 (1), 12-4.

Skibniewska, E.; Kos'la, M.; Skinbniewska, M. (2010). Copper Content in Neoplastic and Healthy Mammary Glands in Dogs. Bull. Vet. Inst. Pulawey. 54, $269-72$.

Skrzydlewska, E.; Sulkowski, S.; Koda, M.; Zalewski, B.; Kanczyqa-Koda, L.; Sulkowska, M. (2005). Lipid peroxidation and antioxidant status in colorectal cancer. World J. Gastroenterol, 11(3), 403-406.

Suleyman, D.; Mustafa, Y.; Mchmet, K.; Natan, A.; Divler, A.; Ahmet, A. (2003). Role of free radicals in peptic ulcer and gastritis. Turk. J. Gastroenterol., 14(1), 39-43.

Sunderman, F.W.; Nomato, S. (1970). Measurement of human serum ceruloplasmine by its para phenylendiamine oxidase activity. Clin. Chem. 16 (11), 903-910.

Tasf, F.; Hasel, H.; Belce, A.; Livan, S.; Camlica, H.; Topuz, E. (2005). Oxidative stress in ovarian cancer. Medical Oncology, 22(1), 11-15.

Valko, M.; Rhodes, C.J.; Monocol, J.; Izakavic, M; Mazur, M. (2006). Free radicals, metals and antioxidants in oxidative stress -induced cancer. Chemico-biological Inleraction, 160, 1-40.

Weinstein, T.; Changanac, A.; Kortezs, A.; Booz, M.; Malachi, T.; Gafter, U. (2000). Hemolysis in hemodialysis patient: againtst oxidative stress. Nephrol. Dial. Transplant, 15, 883-887.

Willard, H.H.; Meritt, L.L.; Dean, J.A. (1974). "Instrumental Methods of Analysis". 5th ed. D. Van Nostrand Company, New York.

William, J.M.; James, F.M. (2004). Oxidative damage to DNA of ovarian surface epithelial cells affected by ovaluation: cancinogenic implication and chemoprevention. Experimental Biology and Medicine, 229, 546-552.

Wolin, K.Y.; Carson, K.; Coldiz, G.A. (2010). Obesity and cancer. Oncologist, 15(6), 556565. 